\title{
A identidade em psicologia social: dos processos identitários às representações sociais
}

DESCHAMPS, Jean Claude; MOLINER, Pascal. A identidade em psicologia social: dos processos identitários às representações sociais. Tradução de Lúcia M. Endlich Orth. Petrópolis: Vozes, 2009.

\section{Géssica Peniche Costa e Silva}

Mestranda em Educação da Pontifícia Universidade Católica do Paraná (PUCPR), Curitiba, PR - Brasil, e-mail: gessicapeniche@pucpr.br

O livro A identidade em psicologia social: dos processos identitários às representações sociais, escrito pelos pesquisadores franceses JeanClaude Deschamps e Pascal Moliner, publicado em 2009 e traduzido por Lúcia M. Endlich Orth da obra original de 2008, L'identité en psychologie sociale - Des processus identitaires aux représentations sociales, integra a coleção "Psicologia social" da Editora Vozes.

Dividida em nove capítulos, a obra conta com o prefácio do conhecido e respeitado professor titular de Psicologia Social da Universidade Estadual do Rio de Janeiro, Celso Pereira de Sá, que destaca a relevância da contribuição da publicação para a área de estudos da psicologia social no Brasil.

Abordar a complexa questão da identidade é algo bastante desafiador, isso porque, ao longo da trajetória do conhecimento humano, 
a importância conferida ao estudo da identidade foi variável, acompanhando a relevância atribuída à individualidade e às expressões do 'eu' nos diferentes períodos históricos e, desse modo, discorrer sobre a identidade pressupõe considerar a intensa diversidade conceitual que a atravessa, expondo-a a inúmeras variações. ${ }^{1}$

Deschamps e Moliner, renomados pesquisadores da área, encaram o desafio e conseguem apresentar, de forma muito objetiva, os processos subjacentes à constituição identitária e trazem uma visão geral de vários temas importantes da psicologia social, destacando a noção de representação como forma de conhecimento sobre si e sobre os outros, que podem interferir no sentimento de identidade.

No capítulo 1, "A semelhança e a diferença", os pesquisadores franceses delineiam os aspectos sociológicos e psicológicos da identidade social e pessoal, marcados, justamente, pelo sentimento de semelhança e diferença em relação aos outros, o que confere à identidade um caráter subjetivo e dinâmico, resultante dessa dupla constatação de semelhanças e de diferenças entre si mesmo e os outros.

Defendendo o princípio de complementariedade entre a identidade pessoal e a social, no capítulo 2, "Os processos identitários", os autores apresentam, de forma integrada e bem consistente, os processos identitários pelos quais construímos o conhecimento sobre nós mesmos e sobre os outros, defendendo que tais processos intervêm na elaboração de conhecimentos e crenças sobre si mesmo, sobre os outros, bem como sobre os grupos de pertença e de não pertença dos indivíduos. Para explicitar cada processo, os autores os dividem em três grandes grupos: processos sociocentrados, que se referem ao tratamento relativo aos grupos sociais, dos quais advêm as categorizações e os estereótipos sociais, visto que permitem aos indivíduos elaborar e organizar seus conhecimentos sobre esses grupos; os processos egocentrados, que, como o próprio nome indica, referem-se ao tratamento das informações relativas aos indivíduos,

1 JACQUES, M. G. C. Identidade. In: STREY, M. N. et al. Psicologia social contemporânea. 5. ed. Petrópolis: Vozes, 2001. 
gerando, assim, conhecimento sobre si mesmo em comparação aos outros. E em meio aos processos sociocentrados e egocentrados estariam os processos intermediários que se referem à informação relativa aos indivíduos, mas que levam em consideração as pertenças desses indivíduos aos diferentes grupos sociais.

No capítulo 3, "Identidade pessoal versus identidade social", os pesquisadores salientam que a maioria dos processos apresentados no capítulo anterior podem produzir efeitos diferenciados, existindo vários modelos teóricos que permitem prever e explicar esses efeitos e a formação das identidades. Na obra são destacados três modelos teóricos: o do conflito objetivo de interesse, o da identidade social e o modelo da covariação. Apoiando-se em Sherif (1961), sobre a teoria do conflito objetivo de interesse, Deschamps e Moliner explicam como as características atribuídas reciprocamente entre os grupos refletiriam as modalidades de suas relações sociais. A partir dos estudos de Tajfel (1972), os autores esclarecem que na teoria da identidade social, de caráter mais motivacional e cognitivo, a identidade social e a pessoal são conceituadas como negativamente interdependentes, já que existe uma oscilação entre uma e outra, para satisfazer a necessidade do indivíduo. De acordo com os estudiosos, no terceiro e último modelo, o da covariação, a identidade social e a pessoal podem ser consideradas como independentes uma da outra, podendo manifestar-se de modo conjunto.

A partir do capítulo 4, "O aporte das representações à problemática da identidade”, são introduzidos alguns aspectos essenciais da noção da representação, deixando claro que as representações não resumem por si só o fenômeno identitário, mas que estas podem intervir no sentimento de identidade.

No capítulo 5, “As representações identitárias", explicita-se como os processos identitários permitem aos indivíduos elaborar e manter conhecimentos a respeito de si mesmo e dos outros, dos diferentes grupos aos quais pertençam e com os quais interagem, e que essas elaborações sociocognitivas são as representações identitárias, uma vez que autorizam e, ao mesmo tempo, cristalizam e sustentam o sentimento de 
identidade. Nesse capítulo, são retomadas algumas questões discutidas nos primeiros capítulos, para elucidar como as representações refletem nos processos que concorrem para a elaboração das representações de si mesmo, dos grupos de pertença e não pertença, que levam os indivíduos a realizarem comparações e constatações de semelhança e/ou diferença.

No capítulo 6, "As representações coletivas", como não poderia ser diferente, há uma referência ao criador do conceito de representação coletiva, Émile Durkheim (1898). Nesse tópico, são feitas as distinções entre o individualismo e o coletivismo nas representações identitárias. Deschamps e Moliner explicitam que tanto as representações individualistas como as coletivistas modulam os processos de categorização e comparação implicados nas construções e nas dinâmicas identitárias, afetando, assim, os conteúdos das representações de si mesmo e intergrupos.

No capítulo 7, “As representações do social”, é feito um recorte muito interessante das dimensões das representações no espaço social, recuperando o conceito de 'campos sociais', postulado pelo sociólogo francês Pierre Bourdieu (1977, 1980). Bourdieu propõe uma descrição do espaço social a partir de duas dimensões estruturantes: o capital econômico e o capital cultural, havendo, portanto, diferentes segmentos e hierarquias na estrutura social. Essas dimensões acabam afetando as representações, uma vez que os grupos dominantes, em virtude do poder que dispõem, impõem normas e representações aos membros dos grupos dominados. De acordo com os autores, nessa perspectiva os indivíduos concebem seus grupos de pertença e não pertença como homogêneos e heterogêneos, em função das representações que eles têm do lugar que esses grupos ocupam na estrutura social.

No capítulo 8, “As representações sociais", são elucidadas a noção das representações sociais proposta por Serge Moscovici (1961). Nesse capítulo, são distinguidos os três grandes modelos teóricos das representações sociais: a abordagem sociogenética, que se interessa pelas representações em formação; a abordagem estrutural, que se concentra nas representações estabilizadas e descreve a sua estruturação interna, com destaque para os estudos realizados por Abric (1987, 1994); e, por último, 
a abordagem sociodinâmica, ou teoria dos 'princípios organizadores', postulada por Doise $(1990,1992)$, que se concentra nas inserções sociais dos indivíduos. Nesse modelo, acredita-se que as representações, ao mesmo tempo em que modulam as relações sociais, são construídas em função dessas relações. Deschamps e Moliner defendem que as representações sociais podem desempenhar o papel de marcador identitário, suscitando tomadas de posição diferentes acerca de um mesmo objeto ou de reguladores que podem organizar a percepção do espaço social em consonância com as aspirações identitárias dos indivíduos.

Finalmente, no capítulo 9, "Processos e representações", os pesquisadores franceses apresentam uma visão integrada dos processos e das representações que interferem no sentimento de identidade. Nesse último capítulo, pontuam a dificuldade de se distinguir o que depende dos processos cognitivos, das transmissões, da aprendizagem, ou até da influência social nesses processos, mas que, independente disso, talvez se deva levar em consideração que esses diferentes fatores remontam à noção de interação social.

Ao fim do livro, os autores trazem um anexo, no qual apresentam diversos métodos de fácil aplicabilidade, que permitem explorar empiricamente alguns dos processos e representações evocados na obra.

Deschamps e Moliner conseguem, definitivamente, evidenciar a importância das representações na problemática da identidade, conduzindo os capítulos de forma muito clara e bem estruturada, proporcionando aos leitores, uma orientação bem objetiva, nem por isso superficial, para os estudos e pesquisas que envolvam essa temática.

Recebido: 04/03/2011

Received: 03/04/2011

Aprovado: 25/04/2011

Approved: 04/25/2011 